\title{
Past, present and future of pastoralism in Greece
}

loannis Hadjigeorgiou

Correspondence: ihadjig@aua.gr Department of Nutritional Physiology and Feeding, Agricultural University of Athens, lera Odos 75, GR-11855, Athens, Greece

\begin{abstract}
Pastoral farming has been a feature of the Greek scene since antiquity. The geomorphology of the area, climatic conditions and the prevailing systems of agricultural production in lowland regions at any given time have all been conducive to the development and preservation of this productive system, principally of small ruminants, until the present day.

In the present paper, a brief review is presented of the pastoralism system in the area of Greece through the millennia, highlighting the variety of driving forces on pastoralism. Importance is stressed on this human activity to the formation of present-day biodiversity.

Over the last decades, the pastoralist system has been subjected to pressures for 'modernization' and intensification like the rest of the agricultural sector in Greece and has been influenced by the social demands and constraints imposed on individuals in the farming community by these same modernising processes. Adaptation to modern conditions has been accompanied by rapid contraction of the pastoral system, despite the noteworthy economic role it purportedly has to play in the national economy, not to mention its social role in keeping alive the steadily decaying mountainous and disadvantaged regions, which constitute a considerable proportion of the rural land area of Greece. An attempt is made to foresee the future of this system by examining the dynamics of each component.
\end{abstract}

Keywords: Greece, nomadism, transhumance, sheep and goats, Mediterranean, European Union CAP

\section{Introduction}

Extensive pastures have traditionally played an important role in the evolution of human societies and the land on which they were living, particularly in the Mediterranean areas (Jouven et al. 2010). Extensive pastures still function today in the production of a range of quality foods (Boyazoglu and Morand-Fehr 2001) and in providing a spectrum of environmental services. Grazing livestock exert a strong impact on the vegetation not only in forage quantity and quality (Bailey et al. 1998), but also on vegetation dynamics (Casasús et al. 2005; Kramer et al. 2003), species and community diversity (Olff and Ritchie 1998; Collins et al. 1998; Sternberg et al. 2000) and, finally, the landscape (Adler et al. 2001; Perevolotsky 2005). Overall, grazing activity significantly contributes to a particularly rich mosaic of vegetation (Balent and Gibon 1996) and results in the creation and preservation of all dimensions of biodiversity (Rook et al. 2004; Clergue et al. 2005; Dover et al. 2011).

The geographical configuration of the Balkan region, with the deep corrugations of its mountain terrain, the high peaks, the frequent alteration between mountain areas

\section{Springer}

(C) 2011 Hadjigeorgiou; licensee Springer. This is an Open Access article distributed under the terms of the Creative Commons Attribution License (http://creativecommons.org/licenses/by/2.0), which permits unrestricted use, distribution, and reproduction in any medium, provided the original work is properly cited. 
and plains with a mild Mediterranean climate and the extensive coastal zones, all guaranteed the availability of summer and winter pasturage without the need to travel over long horizontal distances (Vallerand et al. 2007). From antiquity until the present, the mountainous area of mainland Greece (Pindus mountain range) and that of central Peloponnese have been the summer home for a large part of the migratory flocks of sheep and goats, while coastal areas are the wintering regions. [See map in Figure 1].

A very brief historical account from antiquity to the present shows clearly that the roots of pastoralism as a socio-economic production system lie deep in Greek history. In fact, the ancient Greek word probata ( $л \rho \circ \beta \alpha \tau \alpha)$, which originally meant livestock in general and etymologically 'that which moves ahead', survived intact in modern Greek and refers to sheep. Sheep and goat farming has been the main pastoral activity practised in Greece since ancient times and has survived until today, mainly as part of the national identity, despite not being now a competitive production system (Vallerand et al. 2001; Hadjigeorgiou et al. 2002).

\section{Archaic period}

There are signs of animal farming in Greece more than 8,000 years ago, dated to 6500 B.C. at the beginning of the Neolithic era in Europe (Halstead 1996). In ancient Hellenic societies, animals were essential for the practicalities of farm work and food production, manufacture of garments, transport, war, hunting and sacrifice. Greek myth

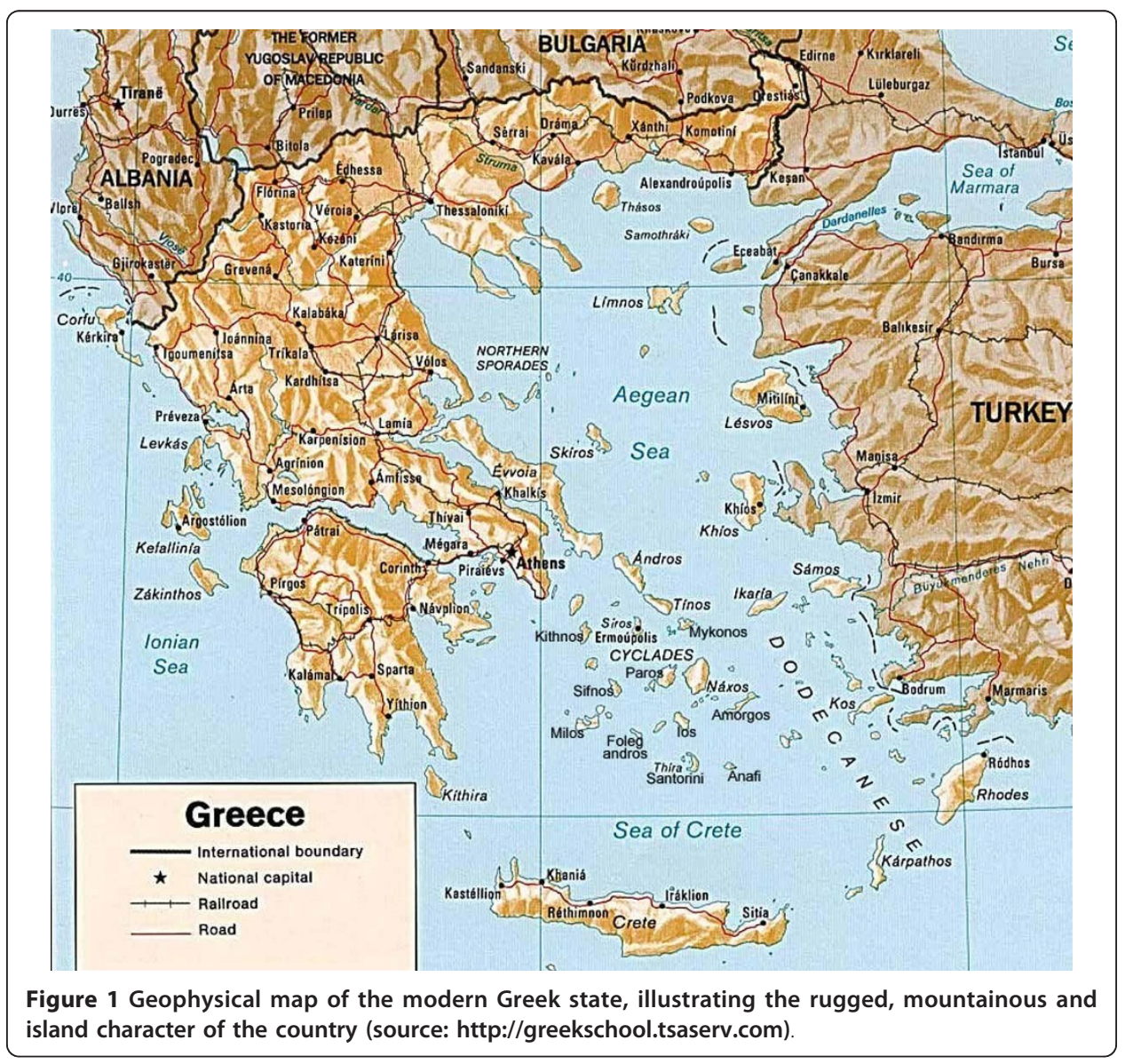


represents real and imagined animals in words and pictures as cultural and conceptual tools.

In antiquity, the relatively low human population density and the low frequency of peaceful intervals meant limits to the area of cultivated land, leaving wide regions open as grazing areas by migratory flocks. Written evidence testifying to the existence of pastoral stock farming is found from as early as the Mycenaean era (sixteenth to thirteenth centuries B.C.). In the surviving corpus of Linear B inscriptions found in Knossos and Pylos palaces, records relating to sheep farming form the largest single component (Halstead 1990).

Later on, Homer (ninth century B.C.) in his epic Odyssey describes some pastoral scenes. However, Hesiod was the first author in antiquity (seventh century B.C.) to report a detailed account of a farmer's life and activities in his poem Works and Days, where he describes pastoral activities, being himself a shepherd for a period. Pastoral stock farming was indeed practised from the earliest recorded history in the Greek territory though of different types and systems (Forbes 1995).

\section{Classical period}

The semi-nomadic pastoral system and mixed arable-livestock farming (mainly of sheep and goats) were possibly predominant in almost all of ancient Greece. Although ancient settlements have been discovered at high altitudes on the Pindus mountains, whether large scale nomadic movements took place is disputed by some modern scholars (Papanastasis et al. 2010). Long-distance transhumance was absent since it required well-developed lowland agriculture, high demand for pastoral products and a politically unified territory, which did not exist at that time (Papanastasis et al. 2010). However, the ancient Graeco-Roman world contained a large variety of landscapes and socio-political conditions, such as forms of land ownership, which would support many different agro-pastoral systems. The Athenian city state was originally founded (twelfth century B.C.) by a tribal society composed of herdsmen, who practised communal livestock holding and pasturage, together with warriors who settled over a comparatively small territorial community. The manorial type of family, together with the concept of wealth, developed gradually and finally shaped social structure so that just before the fifth century B.C., all the land belonged to great landowners, such as the 'Attican Eupatrids' (Metaxas 1955). In Athens, the land ownership crisis was resolved with the arrival of Solon the 'lawgiver' (594 B.C.), who introduced legislation intended to help the peasants (Hammond 1961). Similarly, the reforms of Lycurgus of Sparta led also to a drastic redistribution of the Spartan land, while elsewhere, tyrants also undertook redistributions of land seized from wealthy political enemies. From the fourth century B.C. onwards, property started again to become concentrated among a few land owners, for example, according to Aristotle (384 to 322 B.C.), in Sparta, 'the land has passed into the hands of a few' (Politics, II, 1270a). Nevertheless, the aristocratic estates in Greece never achieved the scope of the great Roman latifundia (White 1967). Xenophon's Economy (fourth century B.C.) provides information on agricultural issues at the time.

Animal husbandry has always been seen as a sign of power and wealth (Forbes 1995). Cattle farming was limited by the inability to expand into less suitable terrain for bovines. Oxen were rare and normally used as work animals though they were 
occasionally used in sacrificial ceremonies. Pigs and poultry were raised, but goats and sheep quickly became the most common livestock since they were less difficult to raise and proved to be successful providers of meat, wool and milk (usually in the form of cheese). Flocks of sheep and goats were herded between the valleys in winter and the mountains in summer, whereas taxes existed for the transit or stopover of flocks in cities (Nixon and Price 2001). Donkeys and mules were raised as pack or draught animals, while horses were raised as a luxury animal, signifying aristocracy.

\section{Roman and Byzantine periods}

During the Roman (146 B.C. to 330 A.D.) and the Byzantine periods (330 to 1453 A. D.), the land area of modern Greece was within a politically unified territory in the Empire, but inhabitants faced conditions which often discouraged arable farming (White 1967). Livestock farming represented one of the most important activities of the Byzantine rural society, judging by the various depictions in art and citations in Byzantine texts. However, nomadic life was considered a characteristic of barbarians since most of the tribes raiding the eastern borders of the Empire practised nomadism. In fact, the belief that 'dairy-fed' tribes (like Scythes, Cumans, Vlachs, Saracens, Alans, Vandals, etc.) were much lower in the scale of civilization than 'wheat-fed' population survived well after the Middle Ages (Leontsini 2008). Nonetheless, the Byzantines treated animal farming as equally important to arable farming in the rural economy; therefore, rules and instructions were produced for the development of both (Laiou and Morrisson 2003). Two almost intact relevant texts have been saved: chapters of the

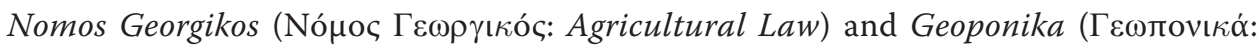
Agronomy Issues). The first text (The Farmers Law /Leges Rusticae, Ed. W. Ashburner, London 1910) is a law code produced by Justinian II (seventh century A.D.) and completed by Leo III (eighth century A.D.). In this text, among others, rules for pastoral activities were set, rights over pastoral areas were defined and penalties for offenders were foreseen. The second text (Geoponica sive Cassiani Bassi scholastici de re rustica eclogae, Ed. H. Beckh, Stuttgart-Leipzig 1895) dated 944 to 959 A.D. is a collection of experts' instructions for agronomy and animal husbandry issues, presented as short essays.

Animal products were very much in demand at Constantinople, the Empire's capital, where the most prominent supply areas were Paphlagonia (at the north of Asia Minor) and the Balkans (Leontsini 2008). However, nomadism, the semi-nomadic system and the household farming of sheep and goats in the Balkans alternated in accordance to political conditions. On one hand, political unification under the Empire enabled the movement of herds and products, but on the other hand, barbarian raids and imperial wars depleted the countryside's people and other resources. The nomadic system centred mainly on the extensive pastures of the large landowners, while semi-nomadic and settled crop farming thrived during war periods when long distance transport was difficult (Laiou and Morrisson 2003).

\section{Ottomans and the Pre-independence period}

During the Ottoman period (1400 to 1830 A.D.), a complex system of land tenure was established. Large estates called tsiflikia (chiftliks) were established in the lowlands by influential members of the ruling system, with the aim of securing the production of 
cereals. However, due to oppression of the people and heavy taxation, the fertile plains were eventually left uncultivated, while the Greek (and Turkish) peasantry concentrated on making small patches of land profitable on the relatively more safe mountains, including pastoralism which exploited the extensive mountain pastures. Under Ottoman rule, a system of nomadic stock farming was gradually developed, known as the great tseligata which became entrenched in the Balkan areas in the seventeenth century, and continued for approximately three centuries. One factor contributing to the flourishing of nomadism in that period was the ease of movement for herdsmen and their flocks throughout the Balkan peninsula as a result of a unified administration under the Ottomans. The basis of the tseligata system was a highly organised system of collaboration between the individual herdsmen and the 'partners' which incorporated many of the basic principles of the rural cooperative (Papageorgiou 1986). The real home of the pastoralist was the mountain, and the centre of mainland Greek pastoralism was the Pindus mountain range, easily reached from the plains and valleys of Thessaly, Sterea Hellas, Epirus and southern Macedonia. The pastoralists shared the highlands with sedentary communities of non-pastoralists, refugees from the plain, who had fled the hardships of the Ottoman rule and most probably of malaria and plague to create a material civilization as impressive as it was fragile (Koliopoulos 1981).

\section{Post-independence up to the twentieth century}

During the nineteenth century and particularly from the time of the establishment of the modern Hellenic state (1832 A.D.), the importance of agriculture for the economy of the young Greek nation was vital (McGrew 1985). Nomadic herding developed with the continued existence of tsiflikia until the land reform of 1922. This system had been limiting the acreage of land open to cultivation and favoured the preservation of pastures and pastoralism, which were always associated with nomadic herding (Gidarakou and Apostolopoulos 1995). However, establishment of the independent state affected central Greek pastoralism in several ways. The most immediate blow was due to the needs of the armies of the Greek irregulars and the mercenaries recruited by the Turks to suppress the revolution. Both sides resorted to the flocks of the local shepherds, who soon hired the services of mountaineer warriors like the Souliotes to protect them (Koliopoulos 1981).

\section{The twentieth century}

At the beginning of the twentieth century, nomadic herding carried on with the same intensity as previously (Koliopoulos 1981). However, soon nomadic herding suffered a fatal blow with the expropriation of the big estates (Gidarakou and Apostolopoulos 1995). As the modern Greek state solidified in territorial terms, it still had to face major problems of restructuring. Moreover, the rural population in Greece suddenly increased, with the arrival of approximately 1.5 million refugees from Asia Minor, after the resolution of the Greco-Turkish War and the Treaty of Lausanne in 1922, which led to a population exchange between Greece and Turkey. The wave of compulsory expropriations, which was dictated by the need to settle the landless (both locals and refugees) and the aim to achieve food autarkia (self-sufficiency), resulted in a sudden increase in cultivated land area, a sharp reduction in grazed areas and a revolution in cultivation methods and strategies. The winter grazing lands were reduced in size, and 
the herdsmen were forced to reduce the size of their flocks or even to give up animal keeping (Gidarakou and Apostolopoulos 1995). In several cases, just before expropriation, herdsmen bought parts or all of the tsiflikia land, which they previously used to rent for grazing, and shifted into arable farming. As a result of these events, a more sedentary system was established, wherein animals were kept in enclosures and supplemented with harvested feeds to increase their productivity.

In 1923, just before the enforcement of the new legislation, a total of 13,700 families were engaged in nomadic herding, with a sheep and goat population of approximately 2.5 million heads (Gidarakou and Apostolopoulos 1995). The tseligata system reached a high level of social organisation, efficiency in resource utilisation and even cultural identity (Chatzimichali 2007). Nevertheless, not long after and during the inter-war period, the tseligata system became almost extinct, due to the new situation. From the period immediately preceding World War II and even more after the war, considerable numbers of nomads purchased winter grazing land as well as arable land to grow animal feeds. Moreover, the few groups which practised pure nomadism (i.e. Sarakatsani, Koutsovlachi and Arvanitovlachi) were obliged after 1938 to register as inhabitants of one or another village (the highland or the lowland) according to Law 1223/38 'for the settlement of stock-farmers' (Koliopoulos 1981).

However, although many stock-farmers abandoned the practice of summer migrations, the migratory sheep and goats still numbered more than 2 million heads in 1960 (Chatzimichali 2007). This figure demonstrates the strong resilience of the system in the period between 1922 and 1960, despite the contraction of winter grazing movements, the large damage suffered by the sector during WWII and the civil war, which followed [see Figure 2]. In fact, during the post-WWII period, the purely nomadic life came to an end. In a 20-year period (1965 to 1984), the migratory sheep flocks were reduced by $27.5 \%$, while the sedentary flocks increased by $15.6 \%$ (Gidarakou and Apostolopoulos 1995). Subsequently, the original transhumance system evolved into transterminance in which the sole purpose of the migration was to ensure availability of pasturage during summer and to avoid the summer drought period. Sheep and goat farming remained a rural activity, where a large share of the livestock was farmed on the less favoured areas (mountain and semi-mountains) of the country [see Figures 3 and 4]. In this context, grazing land maintained its importance for sheep and goat farming, as reflected in a series of the country's censuses [see Figure 5] where for the decades 1961, 1971, 1981 and 1991, grazing land represented a good 40\% of the country's land uses (N.S.S.G 1994). Note that a large part of grazing land (about 60\% ) was 'communal' land, which means owned by the state, and the grazing rights had been transferred to the local municipalities, which then allocated the rights to interested animal farmers. Communal grazing lands were managed by the local councils, consisted of experienced men (tseligas), who decided on the numbers of animals to use the land, the temporal and spatial distribution of flocks, etc.

\section{The European Union period}

The most recent decades have brought further changes in the sheep and goat livestock sector since agriculture became more intensified, partly as a result of Greece joining the European Economic Community in 1981. This intensification is clearly depicted in the change in the areas cultivated with cereals used for animal feeds (maize, barley, 


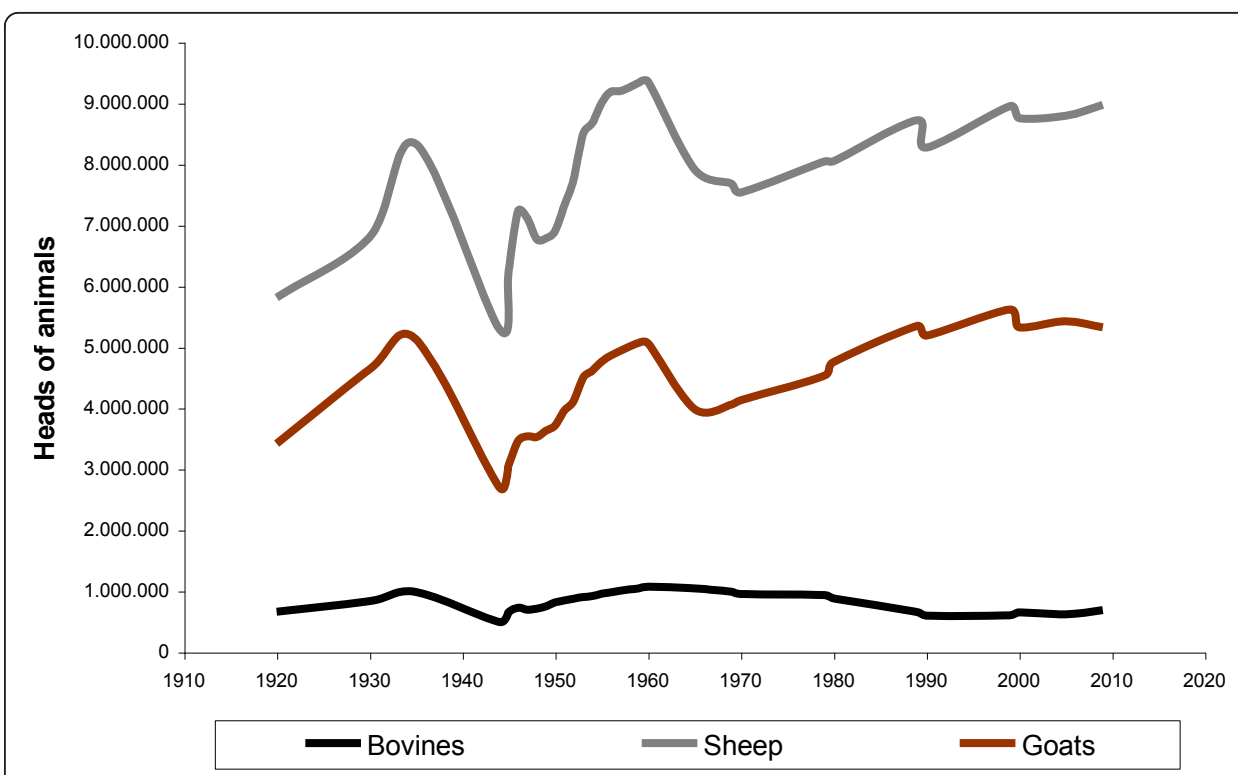

Figure 2 Evolution of farmed ruminants (heads of bovines, sheep, goats) in Greece during the last 100 years (data derived from Hellenic Statistical Authority archives).

oats) as well as their product in a span of 50 years [see Figure 6]. It is clear that although the cultivated land area decreased by about $25 \%$, production increased more than five-fold. This change meant that more sheep and goat farms moved closer to the arable land and settled centres (cities) and relied on harvested feeds. It is not surprising then that the 2000 census recorded a dramatic change in the classification of the landscape, as a result of political priorities, which reduced grazing lands to $11 \%$ of the total national land area (Table 1). This shift in land use class, as recorded in the census, was in favour of 'forests and semi-natural vegetation', which appeals now to the general

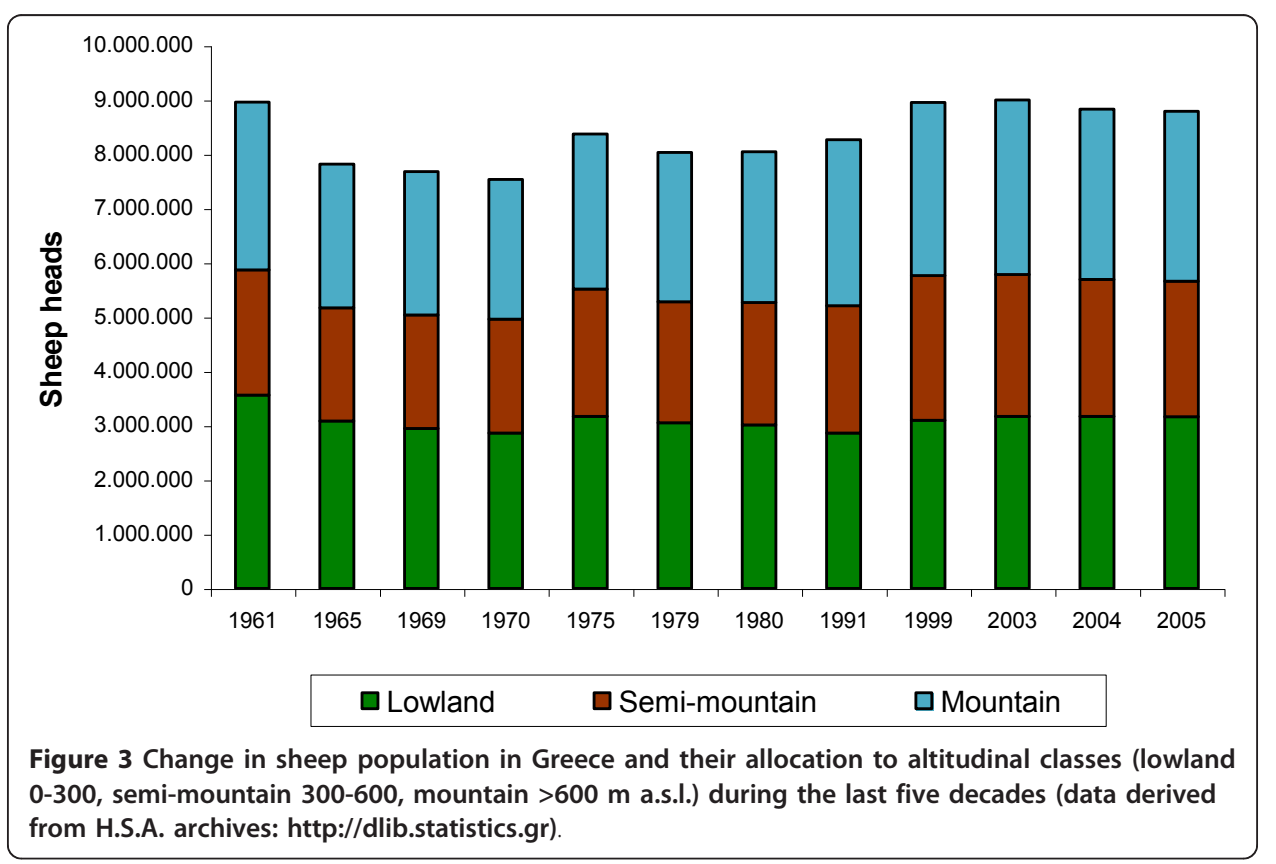




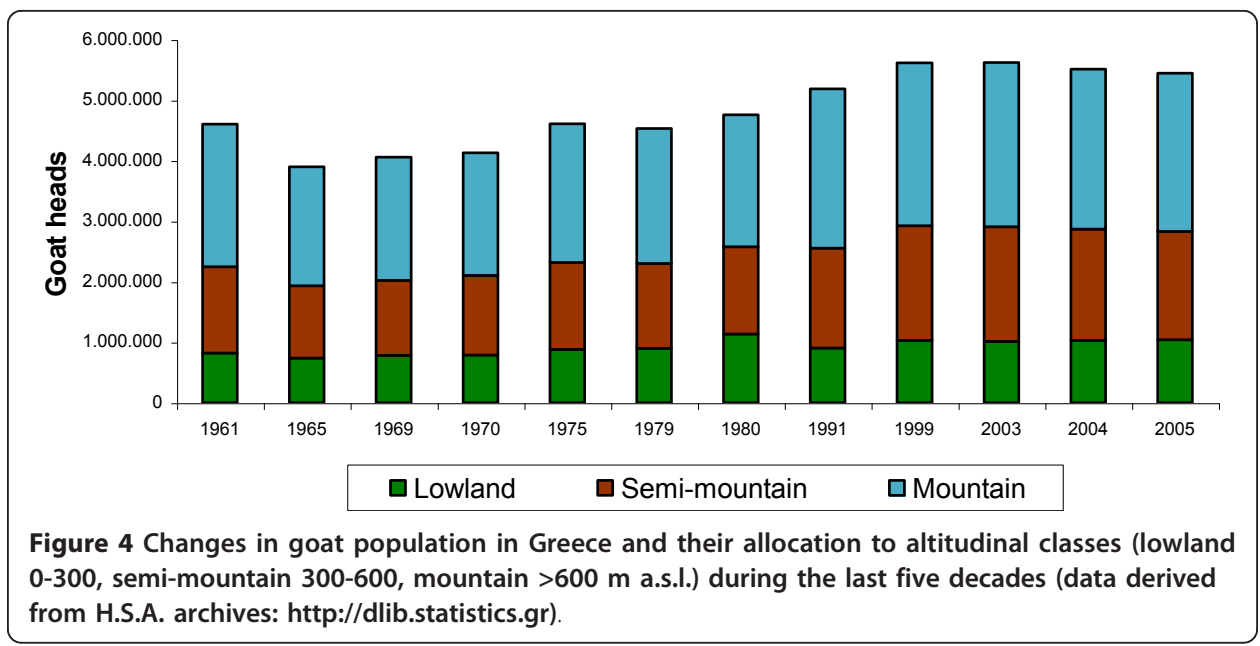

public as a more ecologically friendly land use type, offering environmental services. These and other changes in society brought the dismantling of 'communal pastures' rational management. Local councils were now composed of non-experts regarding pasture, and land was allocated to farmers under purely political criteria.

Another change during the current period is the increase in non-dairy cows kept in extensive farms. These 'suckler cows' amount to more than 200,000 heads, which belong to local breeds and are kept in free-ranging conditions exclusively for the rearing of their calves [Figure 7]. In addition, a type of free-ranging pig farming has also developed, with a relatively small number of local breed pigs utilising the extensive grazing lands.

Organic agriculture is also a recent development in Greek agriculture, employing only $4 \%$ of the 'Utilized Agricultural Area' in 2008. The most important crops of the sector are olives (34\%), fodder crops (27\%) and cereals (26\%), while goats form the largest part (48\%) of the organically farmed stock, followed by sheep (30\%) and poultry $(16 \%)$.

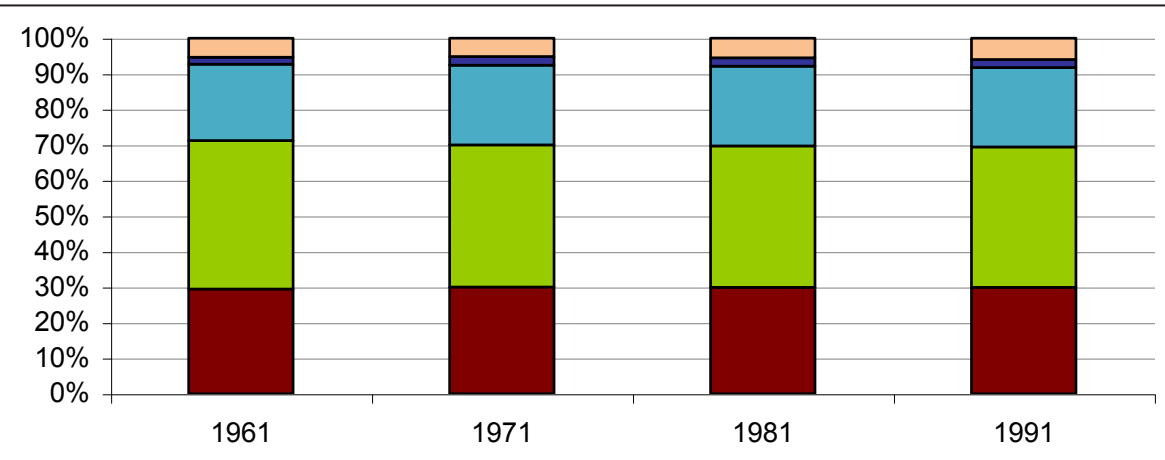

$\square$ Arable \& fallow land $\quad \square$ Grazing land $\quad \square$ Forest land $\quad \square$ Areas under water $\quad \square$ Built \& other areas

Figure 5 Distribution of the Greek land area into major Land Use classes according to official statistics (10 years censuses) between the years 1961-1991 (data derived from H.S.A. archives: http://dlib.statistics.gr). 


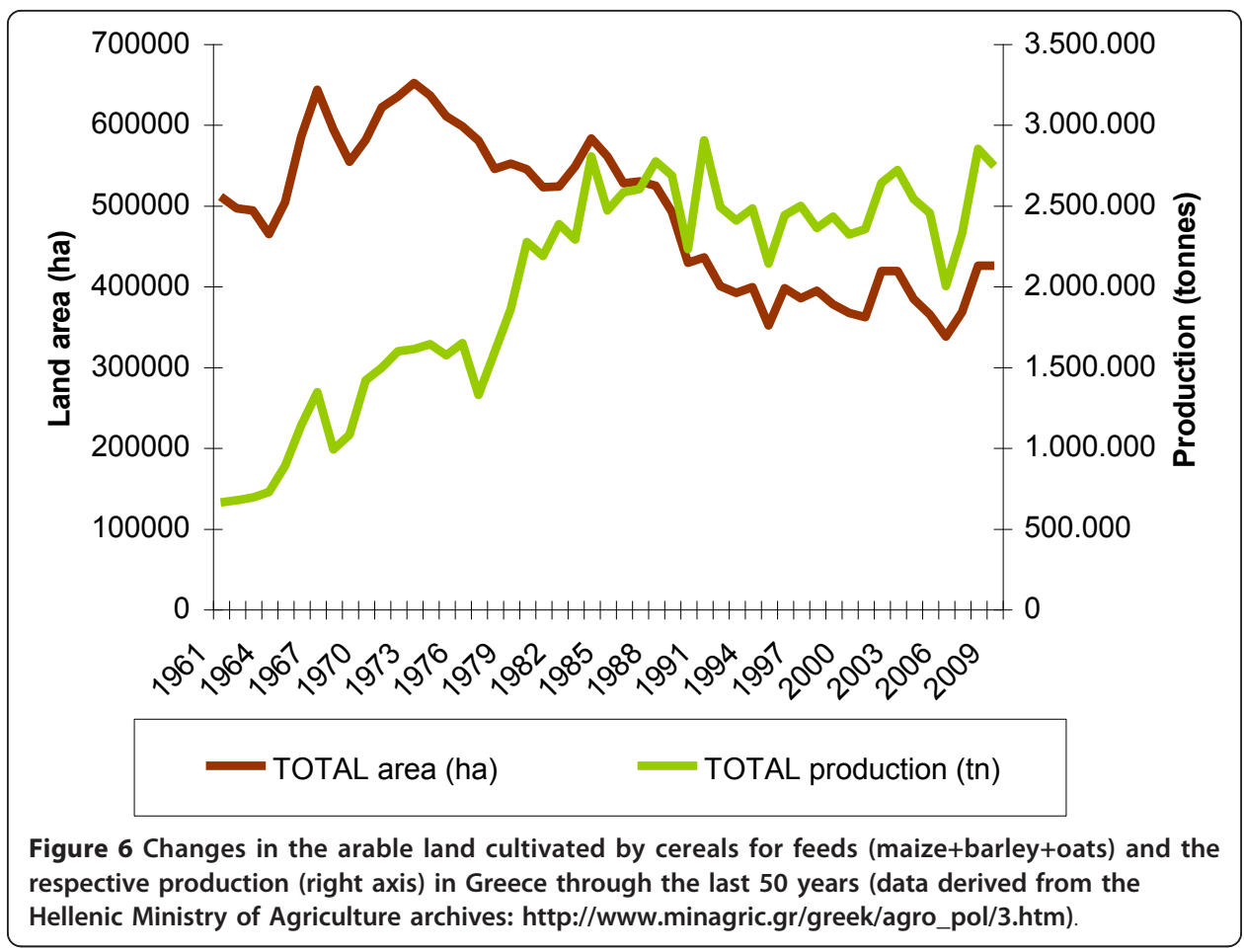

\section{Current livestock and grazing management}

Sheep and goat farms in the country are small (see Table 2. Average size of sheep flocks is 68.1 and goat flocks is 38.5 heads) and are very often mixed farms [Figure 8] also growing cereals, olives, vineyards, tobacco, fruits, vegetables, etc. (H.S.A. 2004), with a low adoption level of technical advances. Therefore, there is always room for improving technical efficiency and increasing farmers' profit. However, since most of

Table 1 Distribution of Greek land area into major land use/cover classes according to recent official statistics

\begin{tabular}{|c|c|c|c|}
\hline Land use/cover classes & $\begin{array}{l}\text { Area }(000 \\
\text { ha) }\end{array}$ & $\begin{array}{l}\text { Percent } \\
(\%)\end{array}$ & \\
\hline Arable land & $21,181.5$ & 16.05 & Agricultural areas (49.36\%) \\
\hline Permanent crops & $7,491.6$ & 5.68 & \\
\hline Pastures - transitional wood land/shrubs & 879.9 & 0.67 & \\
\hline $\begin{array}{l}\text { Pastures - shrub and/or herbaceous vegetation } \\
\text { associations }\end{array}$ & $9,151.5$ & 6.93 & \\
\hline $\begin{array}{l}\text { Pastures - Open spaces with little or no } \\
\text { vegetation }\end{array}$ & $4,420.2$ & 3.35 & \\
\hline Heterogeneous agricultural areas & $22,011.5$ & 16.68 & \\
\hline Forests & $22,411.6$ & 16.98 & $\begin{array}{l}\text { Forest and semi-natural } \\
\text { vegetation areas } \\
(47.43 \%)\end{array}$ \\
\hline Transitional wood land/shrubs & $11,606.6$ & 8.79 & \\
\hline Shrub and/or herbaceous vegetation associations & $23,950.6$ & 18.15 & \\
\hline Open spaces with little or no vegetation & $4,509.3$ & 3.42 & \\
\hline Surfaces under water & $1,790.1$ & 1.36 & \\
\hline Artificial surfaces & $2,577.8$ & 1.95 & \\
\hline TOTAL & $131,982.2$ & 100.00 & \\
\hline
\end{tabular}

Year 2008 Statistical Yearbook of Greece (N.S.S.G. 2009) 


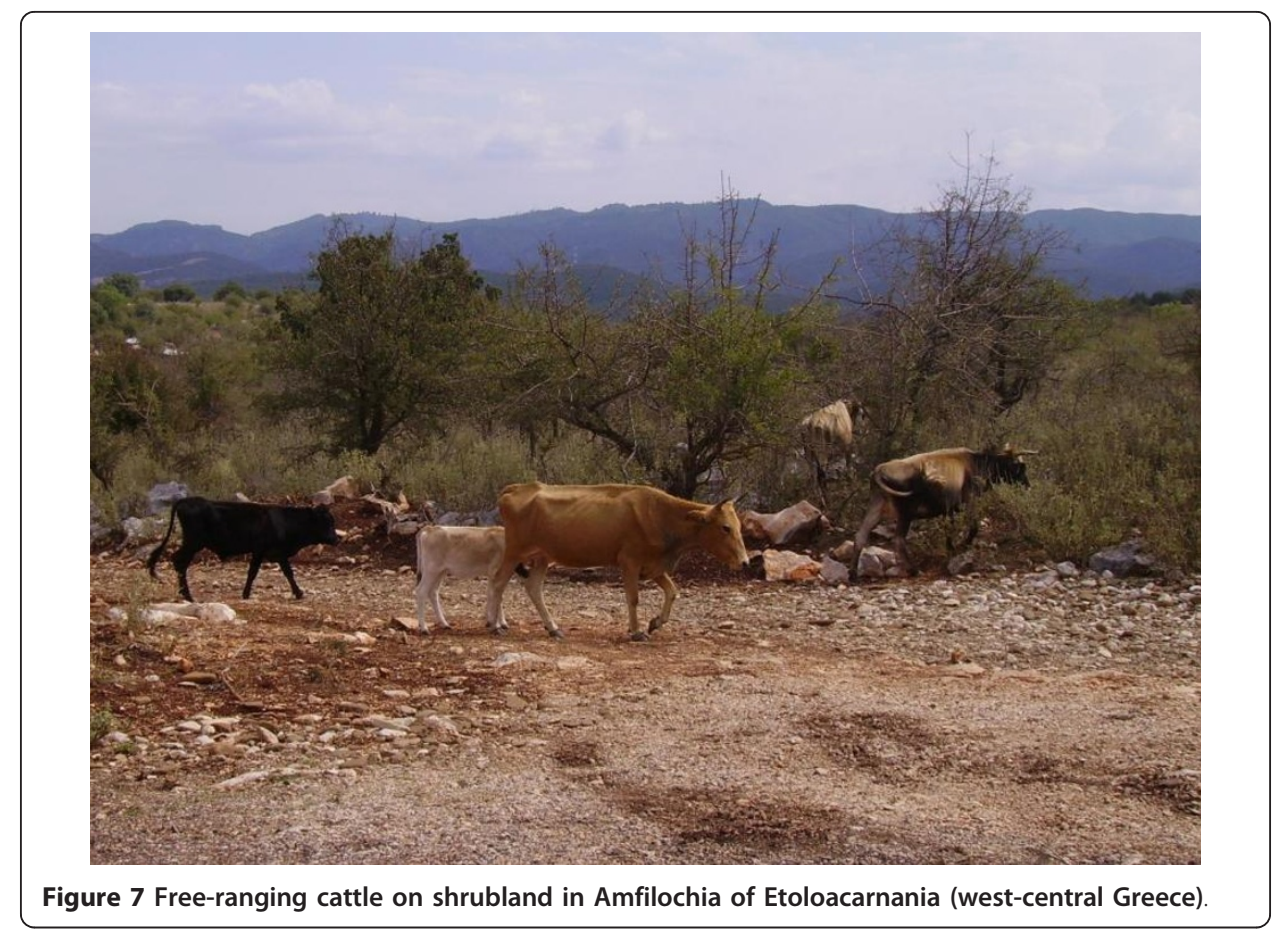

the sheep and goat farmers are elderly and have little formal education qualifications, their adoption of different farming practices or new farming technologies has certain limits (Volanis et al. 2007; Stefanakis et al. 2007; Galanopoulos et al. 2011).

Traditionally, in Greece, grazing has been unfenced and communal (Tsiboukas 1987); sheep and goats were folded during the night (Figure 9), shepherded on mountain pastures during the day and milked in the early morning and late afternoon (Zervas 1998). However, observations suggest that shepherded grazing in mountain regions has gone into a decline in recent decades, and Zervas (1998) warned of problems of both land abandonment and overgrazing in Greek mountains (Figure 10 and 11). Ispicoudis and Chouvardas (2005) cite some data on the depopulation and abandonment of mountain areas; for example, in the study area of the Pindus mountains, a $46 \%$

Table 2 Sheep and goat farms and farmed heads in Greece distributed by farm size classes

\begin{tabular}{lllll}
\hline Size class & $\begin{array}{l}\text { Sheep } \\
\text { (numbers) } \\
\text { Farms }\end{array}$ & Heads & $\begin{array}{l}\text { Goats } \\
\text { (numbers) }\end{array}$ & Farms \\
\hline $1-4$ & 16,693 & 41,412 & 58,843 & Heads \\
\hline $5-9$ & 13,591 & 88,135 & 24,289 & 136,715 \\
$10-29$ & 34,992 & 605,095 & 26,186 & 153,586 \\
$30-49$ & 15,393 & 575,960 & 6,828 & 417,095 \\
$50-69$ & 9,907 & 568,339 & 3,676 & 252,030 \\
$70-99$ & 9,165 & 748,776 & 3,185 & 210,195 \\
$100-199$ & 17,123 & $2,365,144$ & 7,023 & 258,718 \\
200 and over & 11,687 & $3,759,807$ & 8,221 & 982,343 \\
Total & 128,551 & $8,752,668$ & 138,251 & $2,916,519$ \\
\hline
\end{tabular}

According to the 1999 census (H.S.A. 2004). 


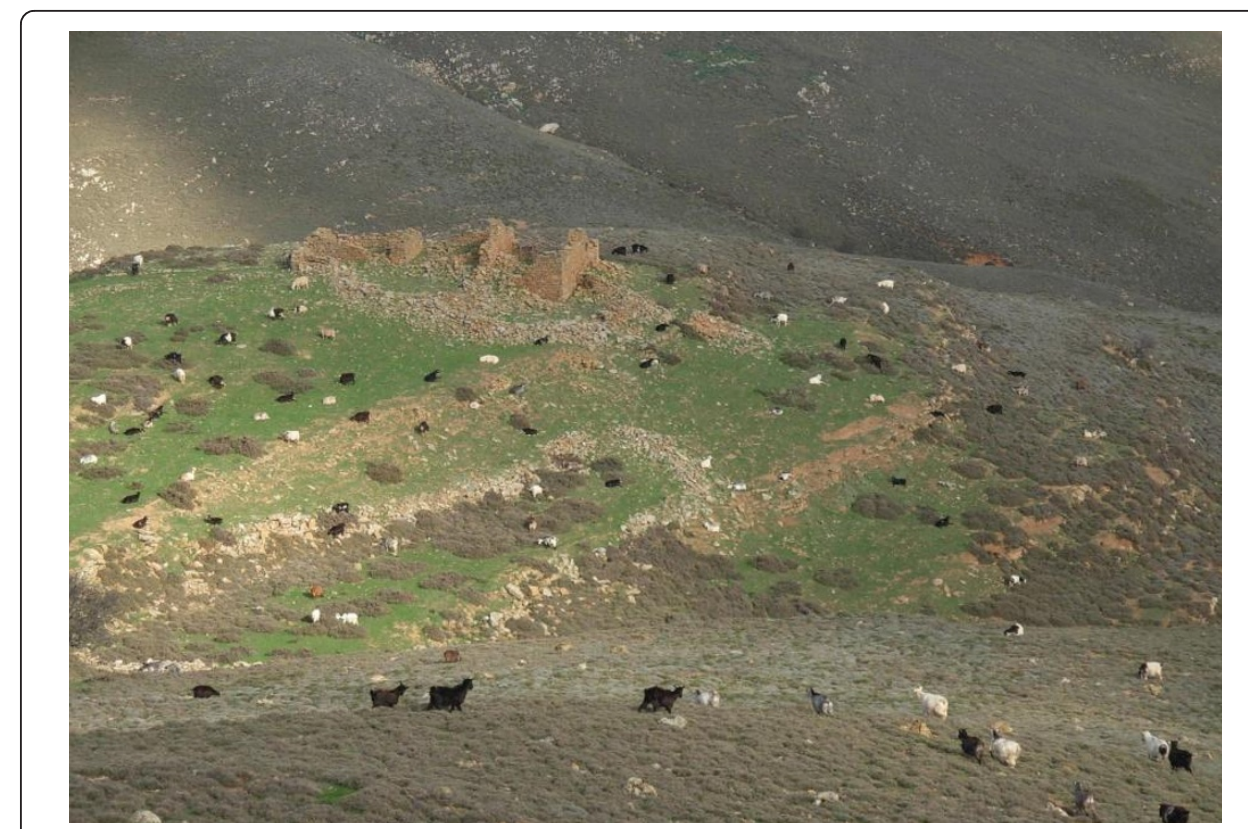

Figure $8 \mathrm{~A}$ mixed flock of sheep and goats foraging on a phryganic community (Sarcopoterium spinosum) at Limnos island in the north Aegean sea.

decrease in cultivated land and a 43\% decline in rough grazings were observed between 1945 to 1992.

Although Hellenic Statistical Authority data document the increase in the national flocks of sheep and goats over the period from 1981 to 2000 (sheep up by $2.3 \%$ to 8.75 million heads; goats up by $12.3 \%$ to 5.3 million heads), this has not been associated with homogeneous grazing patterns of the available land (H.S.A. 2004). Moreover,

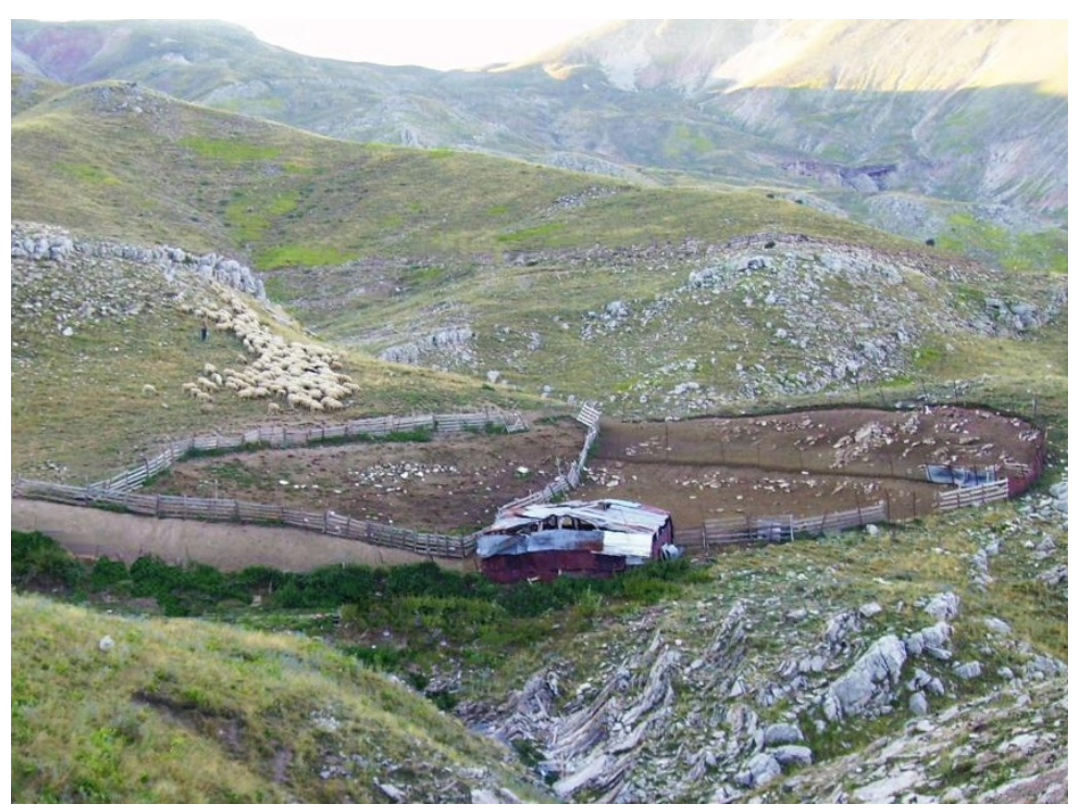

Figure 9 A flock of sheep returning at the end of the day after grazing a high altitude grazing land of Pindus mountain. 


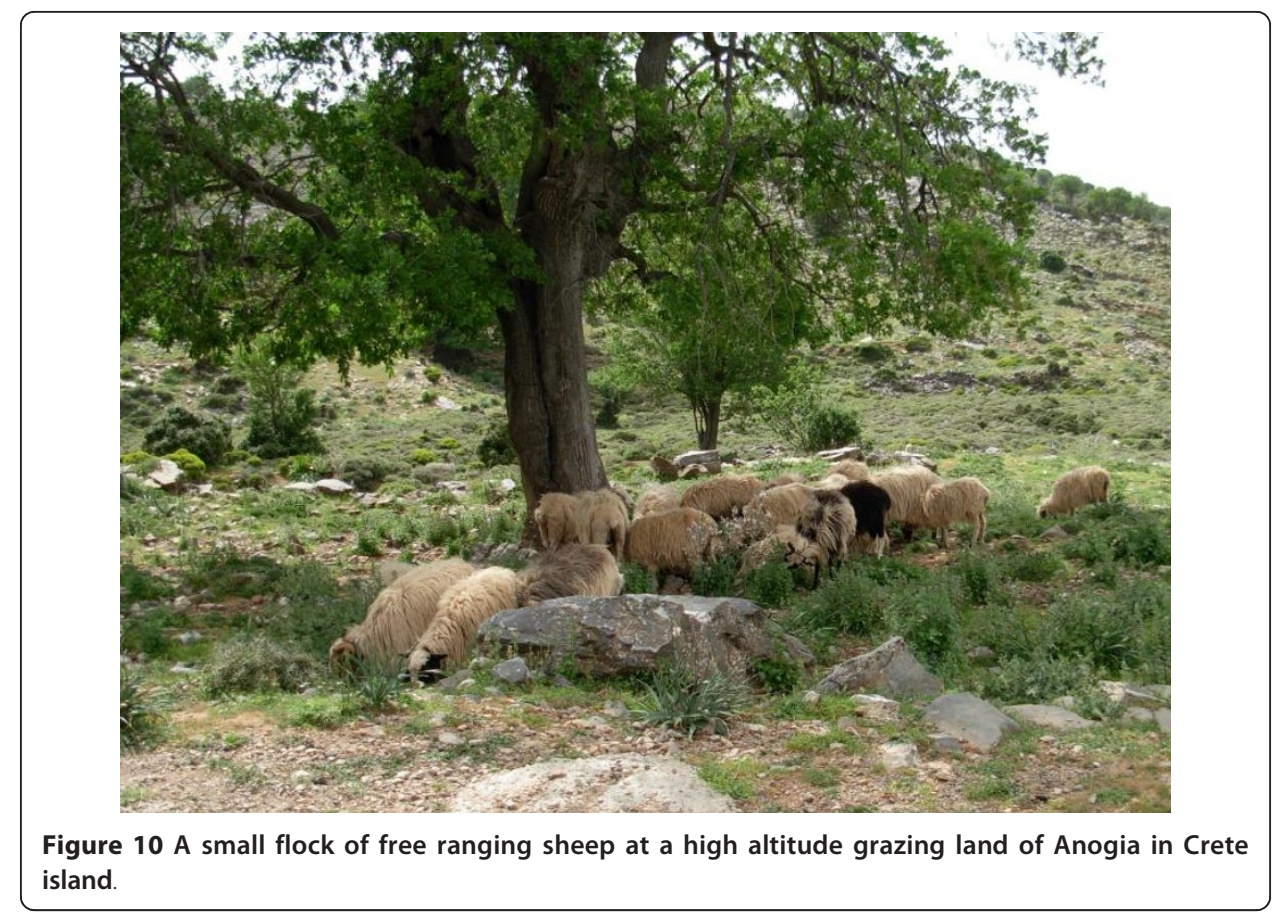

despite the rise in sheep and goat numbers, there is a clear and substantial decrease in the number of farms over the same time period from 1981 to 2000, with sheep (-41.8\% to 128,551 farms) and goats (-60.6\% to 138,251 farms); therefore, uneven grazing patterns are further amplified.

A decrease in farms, coupled with an increase in headage and a translocation to the lowlands, would suggest that enterprises should intensify stock production by feeding

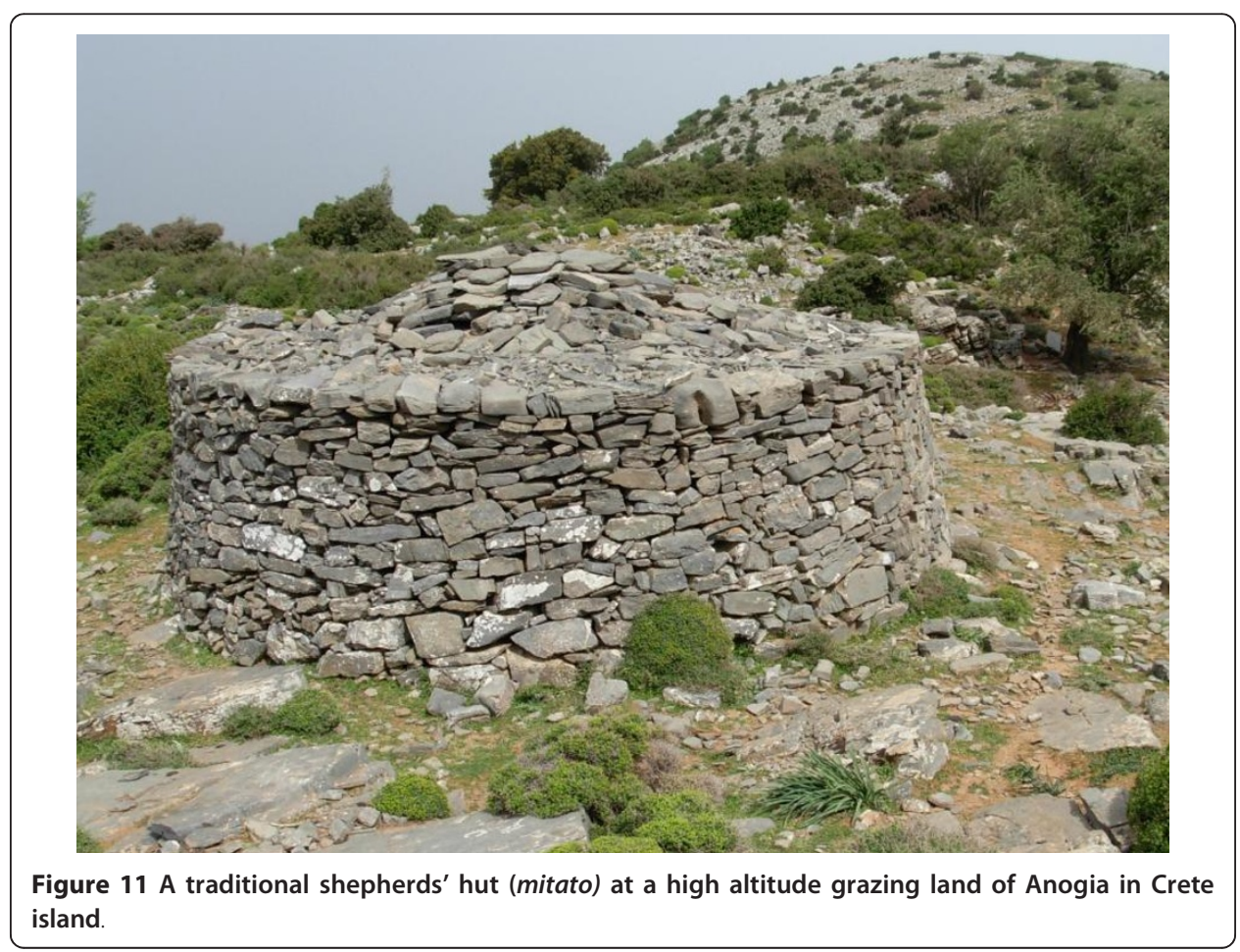


in barns rather than by shepherding or transhumance, especially as much of a sheep and goat farm's income derives from milk production requiring strict hygiene standards and easy access to receiving dairies. Recent legislative changes in Greece now require all dairy sheep and goat farms to have permanent sheds approved by state authorities (Law No 1579 of 1985 as amended by 3698 of 2008) in order to ensure milk and stock hygiene, animal welfare and manure management. However, since this implies significantly higher costs for shed construction and sheds required to be near electricity and water supply networks etc, a greater emphasis on 'home-fed' or sedentarised flocks is observed (Figure 12).

There have been severe consequences of the major decline in recent decades of farming activity in the mountainous and disadvantaged areas of Greece, mainly as a result of modern development forces ('modernization'), with the consequent abandonment of pastoral areas (Zervas 1998; de Rancourt et al. 2006; Hadjigeorgiou and Zervas 2009). This situation has brought changes in vegetation dynamics (mainly invasion of ligneous [woody] vegetation) and therefore in landscape structure and composition (Ispikoudis and Chouvardas 2005). Subsequently, there is an increasing risk of environmental hazards of which the most dramatic is the uncontrolled forest fires (such as those in August 2007 in much of southern Greece, which burned about 270,000 ha of agricultural and forest land), followed by the loss of biodiversity and water economy (Poux et al. 2006). Since unplanned expansion of human settlements has occurred in rural areas, there is a greatly increased risk of loss of life and property due to the wild fires (Keeley 2002) as in 2007 where 63 lives were lost and 1,500 houses burnt to ashes. However, the impacts of mismanaged grazing can also affect the ecosystems negatively through overgrazing, leading to desertification (Arianoutsou-Fraggitaki 1985).

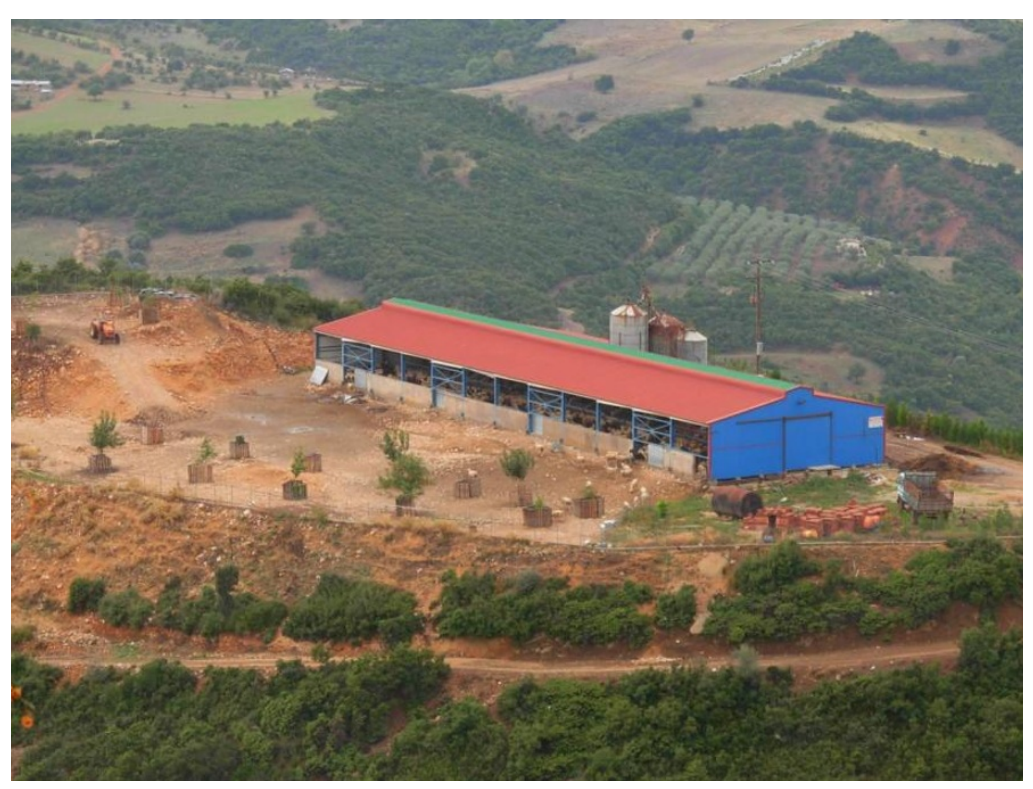

Figure 12 A modern sheep-shed, where sheep are exclusively fed indoors, on a hilly landscape in east-central Greece. 


\section{Livestock farm survey results}

A survey was carried out by the Department of Nutritional Physiology and Feeding at the Agricultural University of Athens, with the aim of analysing the Greek sheep and goat systems at the farm scale and quantifying the role of grazing on animal nutrition as well as the management and conservation of pasture resources. Subsequently, each livestock farmer interested in collaborating (always with the assistance of an expert) completed an appropriate structured questionnaire. The questionnaire recorded basic farm data, i.e. number of animals per category, production output, available grazing areas, utilised harvested feeds, as well as farm infrastructure (housing and machinery) and management issues. Farmers received clear explanations about the purpose of the study in order to provide as reliable information as possible.

A total of 330 questionnaires were completed, representing seven Greek regions. These regions, comprising of Arcadia and Messinia in Peloponesse, Etoloacarnania and Epirus in mainland west, southern Aegean Islands (Rhodes, Ikaria and Fourni), Thessaly in central mainland and Macedonia in the north, differed in terms of physical characteristics, infrastructure available, animal breeding traditions and alternative employment options. Calculations were made on a yearly basis on the per-breeding female animal productivity, the flocks' energetic requirements (MJ NEL) based on NRC (1985) recommendations, the energy supplied through harvested feeds and, by inference, the contribution of grazing to energetic requirements. Data were analysed on a regional basis where it became clear that regions differed $(P<0.001)$ on all flock size, sheep and/or goat heads per holding, milk per adult female in flock, fecundity and the share of grazing to meet energy requirements of the sheep and goats (see Table 3). It was evident that these parameters varied greatly between regions, mainly due to the different region's physical characteristics and the management systems adopted. Average milk productivity varied between regions from 20 to $144 \mathrm{~kg} / \mathrm{year} / \mathrm{breeding}$ female animal. Grazing, mainly of the indigenous vegetation, contributed on average from $20 \%$ up to $70 \%$ of the annual energetic requirements depending on the region (see Table 3), while a strong negative relationship was calculated between this last parameter and milk productivity as follows:

$$
\text { NEL-Grazing }=75.75-0.2391 \times \operatorname{Milk}\left(R^{2}=30.8 ; P<0.001\right)
$$

It was clear that in the regions characterised by a strong tradition in sheep and goat farming and a good infrastructure in milk commercialization, farmers opted for production intensification, and this led to lessening of the grazing contribution to animal feed.

\section{Impacts of the European Union Common Agricultural Policy policies}

The sheep and goat sector in Greece appears to follow an individual pattern through time, not clearly affected by the European Union [EU] Common Market Organization measures. As a general trend, both sheep and goat numbers remained relatively stable, but the number of farms and farm sizes have changed dramatically since joining the EU as stated earlier. Milk production per breeding female, during this period, has increased in sheep from 90 to $100 \mathrm{~kg}$ and remained stable in goats $(120 \mathrm{~kg})$, while the respective figures for national production were higher by $23 \%$ for sheep and $4 \%$ for goat milk (H.M.A. 2011). 
Table 3 Comparative survey data of sheep and goat farms in Greece, classified by region.

\begin{tabular}{llllllll}
\hline Region & Observations & $\begin{array}{l}\text { Flock size } \\
\text { (heads) }\end{array}$ & $\begin{array}{l}\text { Sheep } \\
\text { (heads) }\end{array}$ & $\begin{array}{l}\text { Goats } \\
\text { (heads) }\end{array}$ & $\begin{array}{l}\text { Milk (kg/ } \\
\text { year) }\end{array}$ & $\begin{array}{l}\text { Fecundity } \\
\text { NEL- } \\
\text { Grazing (\%) }\end{array}$ \\
\hline Arcadia & 41 & $231.2 \mathrm{c}$ & $94.5 \mathrm{~b}$ & $136.7 \mathrm{~cd}$ & $103.9 \mathrm{c}$ & $1.14 \mathrm{c}$ & $47.4 \mathrm{c}$ \\
$\begin{array}{l}\text { Aegean } \\
\text { islands }\end{array}$ & 51 & $215.4 \mathrm{c}$ & $42.2 \mathrm{a}$ & $173.2 \mathrm{~d}$ & $20.2 \mathrm{a}$ & $0.96 \mathrm{ab}$ & $61.9 \mathrm{~d}$ \\
Etoloacarnania & 37 & $190.7 \mathrm{bc}$ & $98.6 \mathrm{~b}$ & $92.0 \mathrm{bc}$ & $74.4 \mathrm{~b}$ & $1.03 \mathrm{abc}$ & $66.8 \mathrm{de}$ \\
Epiros & 68 & $129.9 \mathrm{a}$ & $106.6 \mathrm{~b}$ & $23.3 \mathrm{a}$ & $144.4 \mathrm{~d}$ & $1.28 \mathrm{~d}$ & $32.3 \mathrm{~b}$ \\
Makedonia & 17 & $607.9 \mathrm{e}$ & $308.5 \mathrm{c}$ & $299.4 \mathrm{e}$ & $67.4 \mathrm{~b}$ & $0.91 \mathrm{a}$ & $58.5 \mathrm{~cd}$ \\
Messinia & 102 & $144.4 \mathrm{ab}$ & $80.8 \mathrm{~b}$ & $63.6 \mathrm{ab}$ & $64.9 \mathrm{~b}$ & $1.06 \mathrm{bc}$ & $69.2 \mathrm{e}$ \\
Thessalia & 15 & $346.8 \mathrm{~d}$ & $249.6 \mathrm{c}$ & $97.2 \mathrm{abcd}$ & $132.7 \mathrm{~d}$ & $1.01 \mathrm{abc}$ & $19.5 \mathrm{a}$ \\
S.E. & 8.91 & 7.08 & 9.54 & 3.29 & 0.018 & 1.38 \\
$P$ value & & $P<0.001$ & $P<0.001$ & $P<0.001$ & $P<0.001$ & $P<0.001$ & $P<0.001$
\end{tabular}

$\mathrm{a}, \mathrm{b}, \mathrm{c}, \mathrm{d}$, e Figures sharing different letters on the same column differ at $P<0.05$. Significant differences in flock size, sheep and/or goat heads per holding, milk per adult female in flock, fecundity and the share of grazing on covering energy requirements of sheep and goats are observed between the various regions of Greece (A compilation of data produced by the Department of Nutritional Physiology and Feeding at the Agricultural University of Athens).

For a few years after Greece joined the EU, the national policies for support and development of the animal production sector ceased. Among those policies, the most important for the sheep and goat sector was the subsidisation of cereals, which ceased at the end of the 1980s. EU policies affecting the sector such as 'headage payment' (a per animal head subsidy) and 'compensatory premium' (a premium for farmers residing in a 'Less Favoured Area' [LFA] and subsiding mainly on agricultural income) had basically been implemented in the period (1981 to 1992). However, milk and meat consumer prices also increased gradually as a result of the increasing demand; thus, farmers experienced higher incomes.

The stabilisation of headage payment rights after 1992, both at national and individual levels, brought instability in the sector since farmers opted to increase their flocks in order to press for higher quotas and to benefit from high milk prices. Crop subsidies further affected most sheep and goat farming systems since prices decreased also for concentrate feeds, thus leading farmers to utilise them more in feeding their flocks. Then, Greece consolidated, by the Reg. (E.E.C) 1107/96, as Products of Designated Origin [PDO] 20 dairy-farming products (cheeses) of which 18 were made of sheep and goat milk. At that point, a 'milk war' broke out as large dairy enterprises competed in offering high prices for sheep and goat milk, as each aimed to secure a bigger market share in the sector. Nevertheless, overproduction of milk and higher final product prices soon resulted in an over-supply of cheese, so milk prices fell sharply in the subsequent years, gradually returning to the former levels by 2000. A stable period in production and product prices followed until 2005.

The application of E.C. Reg. 1782/2003 at the beginning of 2005 brought a new era in the sector. Full decoupling has been imposed by the Greek government for the sheep and goat sector as it was for most of the Greek agriculture sectors, which meant that production-oriented subsidies would have been paid on a 'historic rights' basis, i.e. a comprehensive subsidy was calculated on the basis of the unitary 2002 headage payment and the farmer's payment rights (calculated as the average of 3 years) and the amount 'frozen' until 2013. This was expected to have positive impacts by favouring the replacement of specialised crop systems with mixed crop and livestock systems and by returning non-profitable arable land to pasture lands. Sheep and goat farmers who 
had grazing land in their 'historic records' had to maintain these lands in good condition by grazing (maintaining a density of $1.4 \mathrm{head} / \mathrm{ha}$ ), while the landless farmers, who used to use 'communal grazing land', had to continue breeding at least $50 \%$ of their animals. The compensatory premium for breeding in the LFAs continued largely unaffected, while some agri-environmental measures (these including extensification and organic farming) were applied sporadically. The implementation of 'cross compliance' rules did not result in many constraints for sheep and goat farmers, except for the animal identification rules, since many traditional farmers were reluctant to enter the system and keep records.

Since EU subsidies comprise a small fraction of farm family income for sheep and goat farmers (Hadjigeorgiou et al. 2002; Galanopoulos et al. 2011), it is expected that the sector will not be seriously affected by the Common Agricultural Policy [CAP] changes in the proposed 2013 reform. Actually, what has been observed in the first 6 years of applying the decoupling system is a small decline in animal numbers, which is considered as non-systematic. Nevertheless, other threats have emerged for the sector, such as the sharp increase in animal feed prices (concentrates and roughages). Since the majority of farmers have been accustomed to using harvested feeds for part of the animal feeding, the cost of feeding their animals has been considerably increased without a respective change in product prices. Concentration of sheep and goats on specialised intensive systems (or very large flocks) is a recent trend (anecdotal data from Ministry of Agriculture and personal observation).

Despite the extensification measures within the agri-environmental policies of the 2000 reformed CAP, a process of livestock farming intensification has occurred in most of the sheep and goat farms in the whole country (Hadjigeorgiou and Zervas 2009). Intensification of the farm management in terms of animal feed inputs is reflected in higher consumption of external inputs (feedstuffs), reduction or cessation of using grazing resources or else reduction of the grazing time period. Intensification is also reflected in upgrading the breeding stock of local sheep (Karagouniko, Chios, Arta, Lesvos, Sfakia, Anogia, etc.), goat (indigenous, Skopelos, etc.) or cattle (Katerini, Brachyceros, etc.) breeds (Georgoudis et al. 20012011) by crossing with exotic higher productivity breeds (Lacaune, Awassi, Assaf for sheep; Zaanen, Alpine for goats; Holstein, Charolais, Limousin for cattle, etc.) which are kept in sheds. The introduction of modern technologies in housing and machinery used (milking parlours, automated feeders etc) are also elements of the present day. Furthermore, the limited labour force available, due to social devaluation of the profession and the hard working conditions, as well as the high opportunity cost of family labour, is hampering extensive pastoral management, as there are fewer experienced shepherds available (Vallerand et al. 20012007). As a consequence of all the above, monthly and annual stocking rates as well as grazing pressure on the local vegetation are considerably lowered nowadays.

\section{Prospects for the future}

Pastoral systems around the world are facing demographic, economic, socio-political and climatic pressures which are driving many pastoralists into non-livestock based livelihood strategies (Ayantunde et al. 2011). Maxwell and Milne (1995) argued that the achievement of sustainable development in pastoral systems depends on achieving intra- and inter-generational equity, environmental integrity and economic efficiency. 
To guarantee inter-generational equity of resources, it is necessary to bring to the forefront the concept of 'reproducibility' (Thomson and Nardone 1999). These authors identified various components of any agricultural system that need to be regularly reproduced if sustainable development is to be achieved: soil fertility, water reservoirs, wildlife co-existence, landscape integrity, human population and economic activity being the most important. Elements that interact and constitute the complex relationship of pastoral systems on rangelands (Snyman 1998) at some point reach equilibrium and may remain as such for considerable periods of time. However, since changes in the reproducibility of a single element can occur, then distortions appear, and the sustainability of the whole system can be threatened. It becomes evident that several elements of the previous different states of equilibrium between livestock farming systems and pastoral resources are again in a transitional mode that could damage the capacity of the pastoral production system to be reproduced.

Since sustainability is not static, its conformation depends on the present and future needs of society (Milne 2005), which are constantly changing (for example, financial demands, environmental and recreation demands, product quality demands and ethical concerns). The sustainable development of grazing lands needs to take into account local or regional conditions rather than applying general models or recommendations (Flamant et al. 1999). For the case of Greece, some relevant conditions are summarised here:

The continuity of pastoral and livestock farming activity does not seem to be threatened purely by product devaluation, high input prices and farm structural or economic restrictions. It is very clear that social factors, related to the absence of farm successors, social devaluation of the pastoral profession and the high opportunity cost of labour will certainly limit pastoral farming activities in the future (Tzanopoulos et al. 2011);

The use of indigenous animals with lower input requirements, which are better adapted to perform adequately under the environmental conditions observed in the Mediterranean area (Bertaglia et al. 2007), will make pastoral systems technically viable;

The decline in livestock grazing at current management and stocking rates encourages the strong vegetation dynamic towards shrub invasion. This is more intense in non-grazed areas (Jouven et al 2010). The shrubby landscapes are defended by public opinion which places higher environmental value on these types of landscape.

It was often claimed that the former system of CAP subsidies in the animal sector (i. e. on a headage basis) was impeding production optimization and biodiversity conservation. However, current CAP biodiversity support schemes (extensification, agroenvironmental premiums) are also implemented at a very low level (e.g. due to a lack of official inspection) regardless of the farming practices actually used (Poux et al. 2006). These schemes have had, therefore, very limited effect in counteracting the intensification process observed in many Greek livestock farms or in promoting the utilisation of bigger pastoral areas or longer grazing periods. Since biodiversity is a complex concept, different indicators need to be pragmatically integrated into a common framework, which is essential for effective biodiversity monitoring and conservation and a basis for result-orientated subsidies (de Bello et al. 2010). 
Greater pressure on pastoral resources does not appear likely, either through an increase in the number of farmers or increases in the national herd size, especially after 'decoupling' in the reformed CAP. This policy has been expected to further lessen the usage of grazing lands, which are mainly communal lands (Poux et al. 2006; Roeder et al. 2007), and indeed, this had been the case (Dover et al. 2011).

The recent trend of 'organic farming' may offer a viable solution to the continuity of extensive farms (Nardone et al. 2004). Pastoral farmers can easily adopt this type of livestock farming since few management changes are needed, whereas there is a considerable financial premium derived from making this change, and there appears to be no risk to the preservation of biodiversity (Hole et al. 2005). However, in relation to current EU organic livestock legislation, particular attention needs to be paid to whether the organic practices are genuine, given the numerous derogations (exemptions allowed by the EC), which affects the public's image of the products (Darnhofer et al. 2010; Zoiopoulos and Drosinos 2010). Other options could be the introduction of additional non-commercial herbivores, managed by the local administrations, to keep a sufficient stocking rate in areas of stronger invasion by shrubs. These 'community serving herds', with no 'direct economic or productive' objective, should be regarded as tools to modulate vegetation dynamics (Bailey et al. 1998). In any case, detailed management plans for the use of grazing resources should be available to local administrations, based on locally derived data.

A recent study commissioned by the European Council acknowledges the urgent need for action to be taken by the European Union to ensure a profitable and sustainable future for sheep and goat farming in the EU (Ernst and Young et al. 2008). This action should retain and attract young sheep and goat farmers to the sector and advocate the maintenance of these traditional, eco-friendly farming enterprises with their role in supplying the EU market with high value farming products and environmental services.

There is an on-going process whereby grazing areas are being concentrated in the easier-to-work parts of the land and where drinking water is available (Hadjigeorgiou et al. 2005). This process is partly due to the reduction in the number of farmers and the subsequent greater land area available for the remaining farms. The uneven grazing pressure between these areas will certainly cause different patterns of change in vegetation and landscapes as well as different risk levels of environmental hazards.

The degradation process of grazing resources in European Mediterranean areas has been extensively discussed in the literature (for example, Balent and Gibon 1996; Zervas 1998; Flamant et al. 1999; Bartolomé et al. 2000). Degradation is followed by a strong tendency towards shrub invasion in the drier areas and forest invasion in the more humid (e.g. mountain) areas. The implications for the landscape and the associated increased risk of fire hazards have been already mentioned, but the negative implications for biodiversity are not often discussed and indeed represent a non-reversible loss (Rook and Tallowin 2003). Although proper stocking densities can control shrub vegetation (Valderrabano and Torrano 2000; Casasús et al. 2005), doubts about the capacity of all domestic animals to efficiently control the dynamics of ligneous plants are also expressed (Bellon and Roggero 1997; Bartolomé et al. 2000). In any case, differences between animal species in their capacity to utilise the range of pastoral resources (Gordon 2003) need to be taken into account. Goats, for example, can 


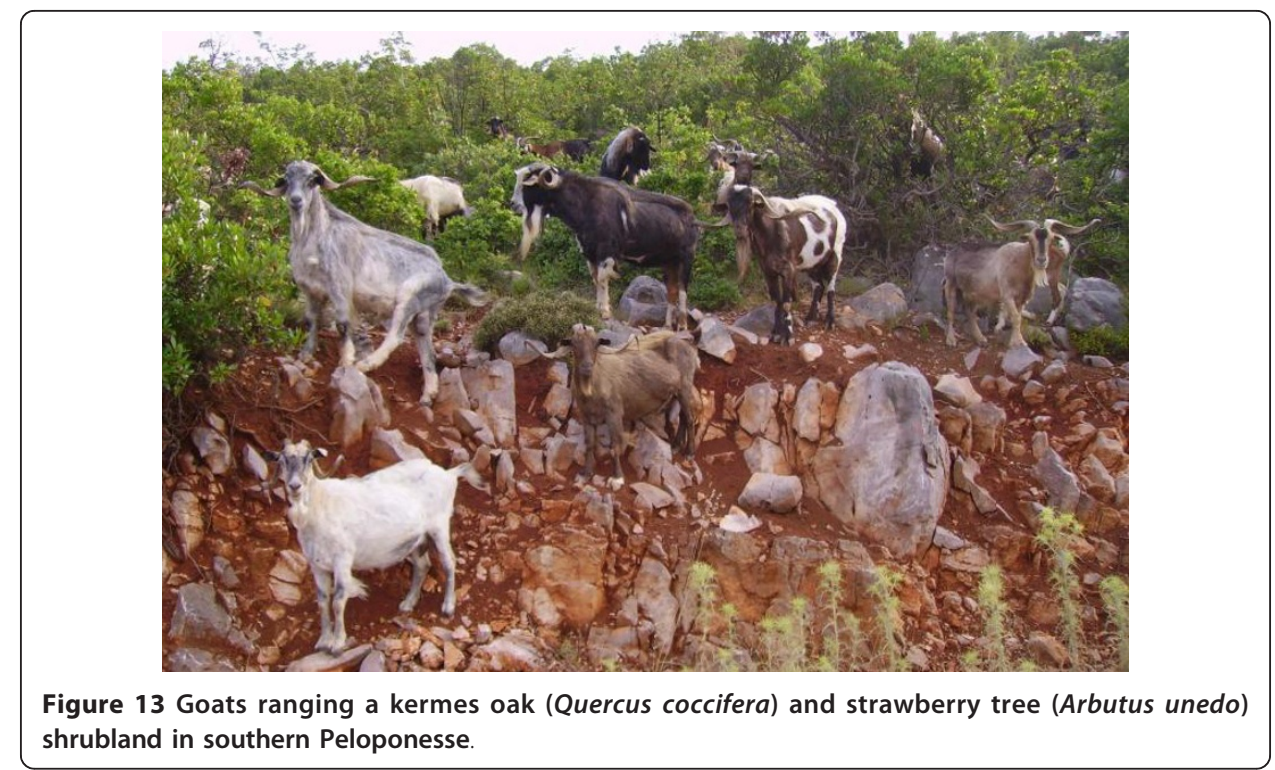

use ligneous vegetation on rough terrain (see Figure 13), while sheep and cattle prefer herbaceous types (Troumbis 2001), but sheep can feed on short grasses more effectively than cattle (Figure 14).

The future of the sheep and goat sector appears relatively secure since it is associated with products having deep cultural roots for Greeks and with products of quality character (PDO). However, the continuity of pastoral (extensive livestock) farm operation is threatened due to the lack of successors and a comparatively high cost for labour (in competition with other economic activities, i.e. tourism). Some farmers, particularly younger ones, reject sheep and goat farming because of the harsh working conditions

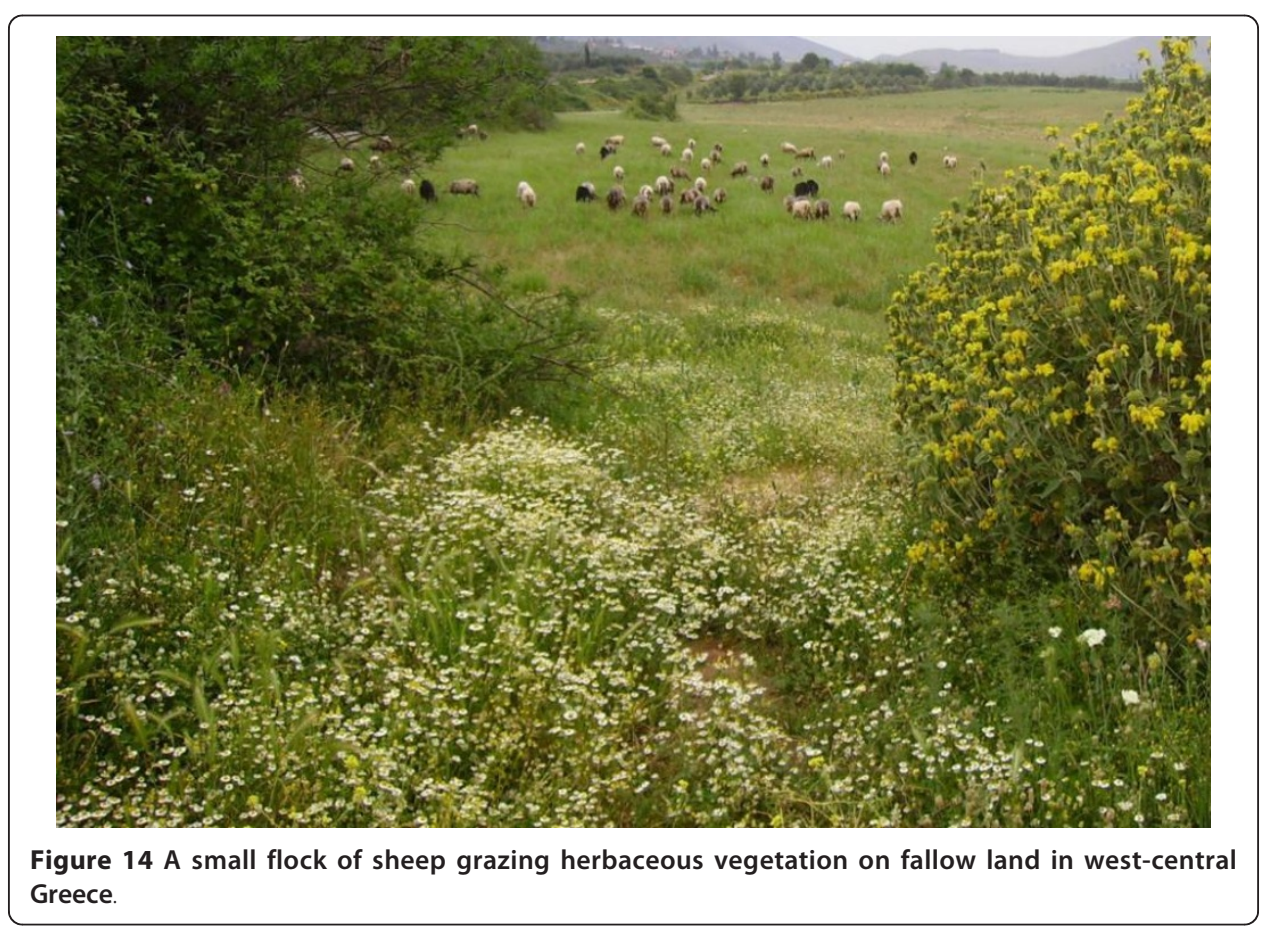


and the low social status associated with this occupation. Moreover, despite the synergy between livestock and tourism activities (the latter is often claimed as an opportunity for rural development), in many cases, the two activities are competing for labour and other local resources, resulting in the tourism sector eventually reducing or substituting for agricultural activities (Teruel et al. 1995; Manrique et al. 1999).

\section{Acknowledgements}

The author gratefully acknowledges Professor George Zervas' permission to use unpublished survey data produced by the Department of Nutritional Physiology and Feeding, the constructive comments of Professor Pantelis Zoiopoulos as well as the advice of Dr. Maria Chroni on pastoralism during the Byzantine era.

\section{Competing interests}

The author declares that he has no competing interests.

Received: 1 July 2011 Accepted: 23 November 2011 Published: 23 November 2011

\section{References}

Adler, P, D Raff, and W Lauenroth. 2001. The effect of grazing on the spatial heterogeneity of vegetation. Oecologia 128: 465-479. doi:10.1007/s004420100737.

Arianoutsou-Fraggitaki, M. 1985. Desertification by overgrazing in Greece: The case of Lesvos island. Arid Environment Journal 9: 237-242.

Ayantunde, AA, J de Leeuw, MD Turner, and M Said. 2011. Challenges of assessing the sustainability of (agro)-pastoral systems. Livestock Science 139: 30-43. doi:10.1016/j.livsci.2011.03.019.

Bailey, DW, B Dumont, and MF Wallis De Vries. 1998. Utilization of heterogeneous grasslands by domestic herbivores: Theory to management. Animal Research 47(5-6): 321-333. doi:10.1051/animres:19980501.

Balent, G, and A Gibon. 1996. Organisation collective et individuelle dans la gestion des ressources pastorales: conséquences sur la durabilité agroécologique des ressources. In The optimal exploitation of marginal Mediterranean areas by extensive ruminant production systems. Volume 83. ed. Zervas G, Boyazoglu J. 365-375. The Netherlands: EAAP Publication, no. 83.

Bartolomé, J, J Franch, J Plaixats, and NG Seligman. 2000. Grazing alone is not enough to maintain landscape diversity in the Montseny Biosphere Reserve. Agriculture Ecosystems and Environonment 77: 267-273, No 89. doi:10.1016/50167-8809(99) 00086-9.

Bellon, S, and PP Roggero. 1997. Elements for sustainable feeding systems in the Mediterranean region. In Livestock farming systems: More than food production. Volume 89. ed. Sørensen JT. 80-86. The Netherlands: EAAP Publication.

Bertaglia, M, S Joost, J Roosen, and . 2007. Identifying European marginal areas in the context of local sheep and goat breeds conservation: A geographic information system approach. Agricultural Systems 94: 657-670. doi:10.1016/j. agsy.2007.02.006.

Boyazoglu, J, and P Morand-Fehr. 2001. Mediterranean dairy sheep and goat products and their quality. A critical review. Small Ruminant Research 40: 1-11. doi:10.1016/S0921-4488(00)00203-0.

Casasús, I, A Bernués, A Sanz, J Riedel, and R Revilla. 2005. Utilization of Mediterranean forest pastures by suckler cows: Animal performance and impact on vegetation dynamics. In Animal production and natural resources utilisation in the Mediterranean mountain areas, ed. Georgoudis A, Rosati A, Mosconi C. 82-88. The Netherlands: EAAP Publication No 115.

Chatzimichali, A. 2007. "Sarakatsani".ed. Ioannou-Giannara T. I and II. The Angeliki Chatzimichali Foundation. (in Greek).

Clergue, B, B Amiaud, F Pervanchon, F Lasserre-Joulin, and S Plantureux. 2005. Biodiversity: Function and assessment in agricultural areas. A review. Agronomie 25(1): 1-15.

Collins, S, A Knapp, J Briggs, and J Blair. 1998. Modulation of diversity by grazing and mowing in native tallgrass prairie. Science 280: 745-747. doi:10.1126/science.280.5364.745.

Darnhofer, I, T Lindenthal, R Bartel-Kratocvhvil, and W Zollitsch. 2010. Conventionalisation of organic farming practices: From structural criteria towards an assessment based on organic principles. A review. Agronomy for Sustainable Development 30: 67-81. doi:10.1051/agro/2009011.

de Bello, F, S Lavorel, P Gerhold, U Reier, and M Partel. 2010. A biodiversity monitoring framework for practical conservation of grasslands and shrublands. Biological Conservation 143: 9-17. doi:10.1016/j.biocon.2009.04.022.

de Rancourt, M, N Fois, MP Lavin, E Tchakerian, and F Vallerand. 2006. Mediterranean sheep and goats production: An uncertain future. Small Ruminant Research 62(3): 167-179. doi:10.1016/j.smallrumres.2005.08.012.

Dover, JW, S Spencer, S Collins, I Hadjigeorgiou, and A Rescia. 2011. Grassland butterflies and low intensity farming in Europe. Journal of Insect Conservation 15: 129-137. doi:10.1007/s10841-010-9332-0.

Ernst and Young, France. 2008. French Livestock Institute and National Experts. The future of the sheep-meat and goat-meat sectors in Europe. Study commissioned by the European Parliament (IP/B/AGRI/IC/2007_043).

Flamant, JC, C Béranger, and A Gibon. 1999. Animal production and land use sustainability. An approach from the farm diversity at territory level. Livestock Production Science 61: 275-286. doi:10.1016/S0301-6226(99)00077-9.

Forbes, H. 1995. The identification of pastoralist sites within the context of estate-based agriculture in ancient Greece: Beyond the transhumance versus agro-pastoralism debate. The Annual of the British School of Athens 90: 325-338.

Galanopoulos, K, Z Abas, V Laga, I Hatziminaoglou, and J Boyazoglu. 2011. The technical efficiency of transhumance sheep and goat farms and the effect of EU subsidies: Do small farms benefit more than large farms? Small Ruminant Research 100(1): 1-7. doi:10.1016/j.smallrumres.2011.05.008. 
Georgoudis, A, A Baltas, C Tsafaras, C Ligda, E Danou, and K Fragos. 2001. Developing biodiversity indicators for the livestock in Greece. Proceedings of an OECD Expert Meeting on Agri-biodiversity Indicators, 5-8 November 2001, Zurich, Switzerland. http://www.oecd.org/dataoecd/9/59/40351142.pdf. (Accessed 10 Oct 2011).

Georgoudis, A, C Ligda, E Karkavelia, A Kotsaftiki, and C Mizeli. 2011. Autochthonous farm animal breeds of Greece. A country report. http://www.rfp-europe.org/fileadmin/SITE_ERFP/country_reports/Greece/Greek_FAbreeds_en.pdf. Accessed 10 Oct 2011.

Gidarakou, I, and C Apostolopoulos. 1995. The productive system of itinerant stockfarming in Greece. Medit , 3: 56-63.

Gordon, IJ. 2003. Browsing and grazing ruminants: Are they different beasts? Forest Ecology and Management 181: 13-21. doi:10.1016/50378-1127(03)00124-5.

Hadjigeorgiou, I, F Vallerand, K Tsimpoukas, and G Zervas. 2002. The socio-economics of sheep and goat farming in Greece and the implications for future rural development. Options Mediterraneennes Series B 39: 83-93.

Hadjigeorgiou, I, K Osoro, JP Fragoso de Almeida, and G Molle. 2005. Southern European grazing lands: Production, environmental and landscape management aspects. Livestock Production Science 96: 51-59. doi:10.1016/j. livprodsci.2005.05.016.

Hadjigeorgiou, I, and G Zervas. 2009. Evaluation of production systems in protected areas: Case studies on the Greek Natura 2000 network. Options Mediterraneennes Series A 91: 101-111.

Halstead, P. 1990. Lost sheep? On the Linear B. Evidence for breeding flocks at Knossos and Pylos. Minos: Revista de filología egea 25: 343-366.

Halstead, P. 1996. Pastoralism or household herding? Problems of scale and specialization in early Greek animal husbandry. World Archaeology 28(1): 20-42. doi:10.1080/00438243.1996.9980329.

Hammond, NGL. 1961. Land tenure in Attica and Solon's Seisachtheia. The Journal of Hellenic Studies 81: 76-98.

H.M.A. 2011. Hellenic Ministry of Agriculture. Agricultural Statistical Data. http://www.minagric.gr/en/agro_pol/3_en.htm. Accessed 10 Oct 2011.

Hole, DG, AJ Perkins, JD Wilson, IH Alexander, PV Grice, and AD Evans. 2005. Does organic farming benefit biodiversity? Biological Conservation 122(1): 113-130. doi:10.1016/j.biocon.2004.07.018.

H.S.A. 2004. Hellenic Statistical Authority: Results of agricultural - livestock census 1999 Athens (in Greek and English). http:// dlib.statistics.gr/Book/GRESYE_02_0902_00034.pdf. Accessed 10 Oct 2011.

Ispikoudis, I, and D Chouvardas. 2005. Livestock, land use and landscape. In Animal production and natural resources utilisation in the Mediterranean mountain areas, eds, ed. Georgoudis A, Rosati A, Mosconi C. 151-157. The Netherlands: EAAP Publication No 115.

Jouven, M, P Lapeyronie, C-H Moulin, and F Bocquier. 2010. Rangeland utilization in Mediterranean farming systems. Animal 4(10): 1746-1757. doi:10.1017/S1751731110000996.

Keeley, JE. 2002. Fire management of California shrubland landscapes. Environmental Management 29: 395-408. doi:10.1007/ s00267-001-0034-Y.

Koliopoulos, JS. 1981. Shepherds, brigands, and irregulars in nineteenth century Greece. Journal of the Hellenic Diaspora 8: $41-53$.

Kramer, K, TA Groen, and SE van Wieren. 2003. The interacting effects of ungulates and fire on forest dynamics: An analysis using the model FORSPACE. Forest Ecology and Management 181: 205-222. doi:10.1016/S0378-1127(03)00134-8.

Laiou, A, and C Morrisson. 2003. New perspectives for a history of the Byzantine economy [Nouvelles perspectives pour une histoire de l'économie byzantine]. Comptes Rendus des Seances de la Academie des Inscriptions et Belles Lettres , 2: $825-855$.

Leontsini, MK. 2008. Shepherds and herds: Concepts on animal farming and animal products in Byzantium. The history of Greek milk and dairy products Proceedings of an Occassional Symposium held on 7-9/10/2005 in Xanthi, Greece 169-191, (in Greek).

Manrique, E, A Olaizola, A Bernués, MT Maza, and A Sáez. 1999. Economic diversity of farming systems and possibilities for structural adjustment in mountain livestock farms. Options Mediterraneennes Series B 27: 81-94.

Maxwell, TJ, and JA Milne. 1995. Role of herbivores in sustainable land production systems. Principles and practice - some of the issues. In Recent developments in the nutrition of herbivores. Proc. of the IV International Symposium on the Nutrition of Herbivores (INRA editions) ed. Journet M, Grenet E, Farce M-H, Thériez M, Demarquilly C. 17-31.

McGrew, WW. 1985. Land and revolution in modern Greece, 1800-81. The transition in the tenure and exploitation of land from Ottoman rule to Independence. Kent, $\mathrm{OH}$ : Kent State University Press.

Metaxas, BN. 1955. Political and social struggles during the Persian and the Peloponnesian wars. In Archives of Economic and social Sciences. Athens ed. Kalitsounakis DE. 35(B): 1-81.

Milne, JA. 2005. Societal expectations of livestock farming in relation to environmental effects in Europe. Livestock Production Science 96(1 SPEC): 3-9. doi:10.1016/j.livprodsci.2005.05.014.

Nardone, A, G Zervas, and B Ronchi. 2004. Sustainability of small ruminant organic systems of production. Livestock Production Science 90: 27-39. doi:10.1016/j.livprodsci.2004.07.004.

Nixon, L, and S Price. 2001. The diachronic analysis of pastoralism through comparative variables. The Annual of the British School of Athens 96: 395-424.

NRC. 1985. Nutritional requirements of sheep. Washington, DC: National Academy Press, 6.

N.S.S.G. 1994. 2001: Statistical yearbook of Greece 1990 - 1991. Athens (in Greek and English). http://dlib.statistics.gr/Book/ GRESYE_01_0002_00045.pdf. Accessed 10 Oct 2011.

N.S.S.G. 2009. Statistical Yearbook of Greece, 2008. Piraeus. (in Greek and English). http://dlib.statistics.gr/Book/ GRESYE_01_0002_00060.pdf. Accessed 10 Oct 2011.

Olff, H, and ME Ritchie. 1998. Effects of herbivores on grassland plant diversity. Trends in Ecology and Evolution 13(7): 261-265. doi:10.1016/50169-5347(98)01364-0.

Papageorgiou, K. 1986. Agricultural cooperatives. Athens: Evgenidio Foundation. (in Greek).

Papanastasis, VP, M Arianoutsou, and K Papanastasis. 2010. Environmental conservation in classical Greece. Journal of Biological Research. 14: 123-135http://uaeco.biol.uoa.gr/files/PDF/papers_int/45_Papanastasis_et_al.pdf.

Perevolotsky, A. 2005. Integrating landscape ecology in the conservation of Mediterranean ecosystems. The Israeli experience Israel Journal of Plant Science 53(3-4): 203-213. 
Poux, X, G Beaufoy, E Bignal, I Hadjigeorgiou, B Ramain, and P Susmel. 2006. Study on environmental consequences of sheep and goat farming and of the sheep and goat premium system. http://ec.europa.eu/agriculture/eval/reports/ sheep2007/full_text_en.pdf. Accessed 9 Oct 2011.

Roeder, N, T Hennessy, and D Stilmant. 2007. Impact of the CAP-reform of 2003 on the use of pastoral land in Europe; In Permanent and temporary grassland - plant, environment and economy. In Grassland Science in Europe ed. De Vliegher A, Carlier A. 12: 445-462.

Rook, AJ, and JRB Tallowin. 2003. Grazing and pasture management for biodiversity benefit. Animal Research 52: 181-189. doi:10.1051/animres:2003014.

Rook, AJ, B Dumont, J Isselstein, K Osoro, MF WallisDeVries, G Parente, and J Mills. 2004. Matching type of livestock to desired biodiversity outcomes in pastures - A review. Biological Conservation 119: 137-150. doi:10.1016/j. biocon.2003.11.010.

Snyman, HA. 1998. Dynamics and sustainable utilization of rangeland ecosystems in arid and semi-arid climates of southern Africa. Journal of Arid Environments 39(4): 645-666. doi:10.1006/jare.1998.0387.

Stefanakis, A, M Volanis, P Zoiopoulos, and I Hadjigeorgiou. 2007. Assessing the potential benefits of technical intervention in evolving the semi-intensive dairy-sheep farms in Crete. Small Ruminant Research 72(1): 66-72. doi:10.1016/j. smallrumres.2006.08.006.

Sternberg, M, M Gutman, A Perevolotsky, ED Ungar, and J Kigel. 2000. Vegetation response to grazing management in a Mediterranean herbaceous community. A functional group approach. Journal of Applied Ecology 37: 224-237. doi:10.1046/j.1365-2664.2000.00491.x.

Teruel, A, A Bernués, and A Caudevilla. 1995. The evolution of the tourism and livestock sectors in the Pyrenean region of Jacetania. EAAP Publication 74: 265-269.

Thomson, PB, and A Nardone. 1999. Sustainable livestock production: Methodological and ethical challenges. Livestock Production Science 61: 111-119. doi:10.1016/S0301-6226(99)00061-5.

Troumbis, A. 2001. The ecological role of cattle, sheep and goats. Encyclopedia of Biodiversity. Academic Press 1: 651-663.

Tsiboukas, K. 1987. The forms of pastoral use of the Greek mountains: The example of Thessalie [Les formes d'utilisation pastorale de la montagne grecque: l'exemple de la Thessalie]. Bulletin - Societe Languedocienne de Geographie 21(3-4): 247-261.

Tzanopoulos, J, AS Kallimanis, I Bella, L Labrianidis, S Sgardelis, and JD Pantis. 2011. Agricultural decline and sustainable development on mountain areas in Greece: Sustainability assessment of future scenarios. Land Use Policy 28: 585-593. doi:10.1016/j.landusepol.2010.11.007.

Valderrabano, J, and L Torrano. 2000. The potential for using goats to control Genista scorpius shrubs in European black pine stands. Forest Ecology and Management 126: 377-383. doi:10.1016/50378-1127(99)00108-5.

Vallerand, F, JP Dubeuf, and K Tsiboukas. 2007. Le lait de brebis et de chèvre en Méditerranée et dans les Balkans: diversité des situations locales et des perspectives sectorielles. Cahiers Agricultures 16(4): 258-264.

Vallerand, F, K Tsiboukas, and L Kazakopoulos. 2001. A Greek paradox: Omnipresent sheep and goat farming but neglected because of development structures; how to improve it? Options Mediterraneennes Series A 46: 189-194.

Volanis, M, A Stefanakis, I Hadjigeorgiou, and P Zoiopoulos. 2007. Supporting the extensive dairy sheep smallholders of the semi-arid region of Crete through technical intervention. Tropical Animal Health and Production 39(5): 325-334. doi:10.1007/s11250-007-9019-z.

White, KD. 1967. Latifundia: A critical review of the evidence on large estates in Italy and Sicily up to the end of the first century A.D. Bulletin of the Institute of Classical Studies 14(1): 62-79. doi:10.1111/j.2041-5370.1967.tb00048.X.

Zervas, G. 1998. Quantifying and optimizing grazing regimes in Greek mountain systems. Journal of Applied Ecology 35: 983-986. doi:10.1111/j.1365-2664.1998.tb00019.x.

Zoiopoulos, PE, and EH Drosinos. 2010. The animal feed question in the shadow of contemporary food crises: The European challenge. New York: Nova Science Publishers.

doi:10.1186/2041-7136-1-24

Cite this article as: Hadjigeorgiou: Past, present and future of pastoralism in Greece. Pastoralism: Research, Policy and Practice 2011 1:24. 